\title{
Side \\ First report of citrus bacterial blast and citrus black pit caused by Pseudomonas syringe pv. syringae in Tunisia
}

\author{
E. Abdellatif ${ }^{1 *}$, M. Kaluzna $^{2}$, F. Helali ${ }^{3}$, M. Cherif $^{4}$, J.D. Janse ${ }^{5}$ and A. Rhouma ${ }^{1}$ \\ ${ }^{1}$ Laboratoire d'Amélioration et Protection des Ressources Génétiques de l'Olivier, Institut de l'Olivier BP 208, Cité \\ Mahrajène, 1082 Tunis, Tunisie; ${ }^{2}$ Research Institute of Horticulture, Division of Pomology, Konstytucji 3 Maja 1/3, 96-100 \\ Skierniewice, Poland; ${ }^{3}$ Laboratoire de Quarantaine, Ministère de l'Agriculture, Tunisie; ${ }^{4}$ Centre Technique des Agrumes, \\ BP 318, 8099 Zaouiet Jedidi, Beni Khalled, Tunisie; ${ }^{5}$ Department of Laboratory Methods and Diagnostics, Dutch General \\ Inspection Service (NAK), PO Box 1115, 8300 BC Emmeloord, The Netherlands
}

*E-mail: abd_emna@yahoo.fr

Received: 24 Apr 2015. Published: 30 Dec 2015. Keywords: Citrus sinensis, Citrus limon, bacterial plant disease

During recent years (2013-2015) a disease similar to citrus bacterial blast of orange (Citrus sinensis) and citrus black pit of lemon (Citrus limon) has been observed in Tunisian citrus orchards. In a recent survey 35 infected orchards were located in almost all known citrus-growing regions in Tunisia (with a concentration in the Cap Bon region, North Tunisia).

Symptoms were blasted flowers and buds, spotted and blistered fruits, stem cankers, leaf blights and plant dieback in both orange and lemon (Figs. 1, 2). Leaf symptoms were black discolored areas, often at the junction of leaf blade and petiole wings. Spotted orange fruits were rarely found, but blasted lemon plants were frequently observed and the latter symptom was not previously reported. Eighty bacterial isolates were obtained, producing fluorescent pigment on King's B medium and white, glistening, convex colonies on nutrient sucrose agar (NSA). Isolates produced a hypersensitive reaction on tobacco (Nicotiana tabacum)

Fourteen isolates were selected for further study using methods described by Lelliot \& Stead (1987). They were all Gram negative, and belonged to LOPAT group Ia. Strains GBBC1158 (P. viridiflava, Veronica austriaca, Belgium), GBBC748 (P. syringae, Malus, Belgium) and IO527 (P.s. pv. morsprunorum race1, Prunus avium, Poland) were included as references. Identity was further confirmed by PCR using primers Ps-for and Ps-rev (Widmer et al., 1998) specific to the Pseudomonas genus. Also presence of genes encoding synthesis of the toxin syringomycin was confirmed (Bultreys \& Gheysen, 1999). Strain LMG1247 (P.s. pv. syringae, Syringa vulgaris, UK) was used as reference. Twelve isolates were positive with PCR. All of them possessed the $s y r B$ gene and eleven the $s y r D$ gene. Partial 16S rRNA sequences for seven isolates (LN876273-LN876279) showed highest similarity (97-99\%) to P.s. pv. syringae strains KFB 93 (JQ071937), XJLX-2-2 (KC816630), XJLX-8-3 (KC816627), HH-02 (KF500097), XJLX-2-2 (KC816630), IZB228 (KP099979) and XJLX-8-3(KC816627). Additionally, rpoD sequence analysis (LN876268-LN876272), according to Sawada et al. (1999), showed that our isolates belong to P.s. pv. syringae.

Pathogenicity was tested on citrus fruits, twigs and plantlets (cvs. Eurêka, Washington Navel, Maltaise and Cassar) which were inoculated with a $10^{8} \mathrm{cfu} / \mathrm{ml}$ bacterial suspension. Sterile distilled water was used as control. Seven days after inoculation on fruits small black areas about 2 to $5 \mathrm{~mm}$ in diameter, surrounded by a greenish zone were formed. Twigs and plantlets showed typical blast symptoms. To fulfill Koch's postulates, bacteria were re-isolated from plant tissue with symptoms, and identity was confirmed based on colony morphology on King's B and NAS media. Identity was validated as well by LOPAT, GATTa tests and ERIC, REP and BOX PCR (according to Louws et al., 1994). The re-isolated bacteria were HR positive. A phylogenetic based on rep-PCR data showed them similar to originally inoculated isolates and most closely related to P.s. pv. syringae strain LMG 5496, isolated from citrus. To our knowledge, this is the first report of the occurrence of citrus bacterial blast/citrus black pit and their causal agent P.s. pv. syringae in Tunisia.

\section{Acknowledgements}

The authors thank Dr. Samir Chebil and Ms Synda Chenenaoui from the Biotechnology Center of Borj-cedria for their much appreciated assistance.

\section{References}

Bultreys A, Gheysen I, 1999. Biological and molecular detection of toxic lipodepsipeptide-producing Pseudomonas syringae strains and PCR identification in plants. Applied and Environmental Microbiology 65, 1904-1909.

Kałużna M, Puławska J, Sobiczewski P, 2010.The use of PCR melting profile for typing of Pseudomonas syringae isolates from stone fruit trees. European Journal of Plant Pathology 126, 437-443.

http://dx.doi.org/10.1007/s10658-009-9553-9

Lelliot RA, Stead DE, 1987. Methods for the diagnosis of bacterial diseases of plants. In: Preece TF, ed. Methods in Plant Pathology, Volume 2. Oxford, UK: Blackwell Scientific Publications, 216.

Louws FJ, Fulbright DW, Stephens CT, de Bruijn FJ, 1994. Specific genomic fingerprinting of phytopathogenic Xanthomonas and Pseudomonas pathovars and strains generated with repetitive sequences and PCR. Applied and Environmental Microbiology 60, 2286-2295.

Sawada H, Suzuki F, Matsuda I, Saitou N, 1999. Phylogenetic analysis of Pseudomonas syringae pathovars suggests the horizontal gene transfer of argK and the evolutionary stability of hrp gene cluster. Journal of Molecular Evolution 49, 627-644. http://dx.doi.org/10.1007/PL00006584

Widmer F, Seidler RJ, Gillevet PM, Watrud LS, Di Giovanni GD, 1998. A highly selective PCR protocol for detecting 16S rRNA genes of the genus Pseudomonas (sensu stricto) in environmental samples. Applied and Environmental Microbiology 64, 2545-2553.

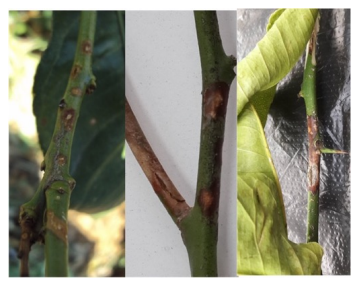

Figure 1

Figure 2

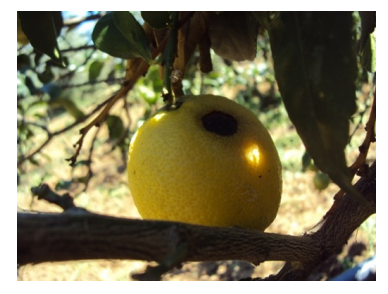

To cite this report: Abdellatif E, Kaluzna M, Helali F, Cherif M, Janse JD, Rhouma A, 2015. First report of citrus bacterial blast and citrus black pit caused by Pseudomonas syringe pv. syringae in Tunisia. New Disease Reports 32, 35.

http://dx.doi.org/10.5197/j.2044-0588.2015.032.035

(C) 2015 The Authors

This report was published on-line at www.ndrs.org.uk where high quality versions of the figures can be found.

New Disease Reports is a peer-reviewed on-line journal published by the British Society for Plant Pathology,

for more information visit http://www.ndrs.org.uk/ 